\title{
The European Assemblage: A Discursive- Material Analysis of European Identity, Europaneity and Europeanisation
}

\author{
NICO CARPENTIER
}

Charles University, Opletalova 38, 11000 Praha 1, Czech Republic; Vrije Universiteit Brussel, Pleinlaan 2, Belgium; Institute of Communication Studies and Journalism, Faculty of Social Sciences, Smetanovo nábř. 6, 11000 Praha 1, Czech Republic

Email: nico.carpentier@fsv.cuni.cz

\begin{abstract}
Different academic disciplines have deployed a diversity of approaches to European identity, Europeanism and Europeanisation, with often a strong emphasis on their material-structural components. This article uses a discursive-material analysis, that acknowledges the importance of the material, but places it in a non-hierarchical relation with the discursive. Grounded in an extensive literature review on European identity, Europeanism and Europeanisation, the article first highlights the discursive nature of these concepts, how they engage in struggles with other place-based identities and discourses, and how the articulations of these concepts themselves are deeply contingent, with a long history of essentialist articulations. In the second part, the material components of these three concepts (and in particular Europeanisation) are analysed, then allowing for a plea to understand Europe as an assemblage, where Europe is seen to be performed in always unique and contingent articulations of the discursive and the material.
\end{abstract}

Keywords: European identity, Europeanism, Europeanisation, being European, becoming European, discourse theory, new materialism, entanglement, assemblage

\section{INTRODUCTION}

Europe is many things, but it is also an idea, or - as Rietbergen (2015: xxxv) writes - 'a political and cultural concept' that gives meaning to 'the western edge of Eurasia, the earth's largest land mass'. This reference to Rietbergen's work already indicates that our thinking about Europe combines discursive ('concept') and material ('land mass') components, but at the same time it is remarkable how dominant the material-structural analyses in particular academic fields (e.g. media studies and political studies) remain, and how rare analyses of the entanglement of these two components in general are.

This article organises a reflection on Europe through the lens of the discursive-material knot (Carpentier 2017), a theoretical model of entanglement, grounded in the articulation of discourse theory and new materialism. Three concepts will serve as entry points into these discussions - European identity, Europaneity and Europeanisation - first emphasising their discursive nature, and the contingency of their articulation, and then shifting gear to analyse 
their - and in particular Europeanisation's - material dimensions. These two analyses then support the idea of the European assemblage, as always particular, changeable and politically contested articulations of Europe's discursive and material components.

\section{DISCURSIVE CONSTRUCTIONS OF IDENTITY AND SPACE}

The relationship between identity and space is complex, mediated through a variety of discursive constructions. One starting point to reflect about this relationship is through the concept of the nation. While more primordialist versions of the nation bring out an essentialist argumentation, grounded in kinship and common descent, authors such as Anderson (1996: 4) - in Imagined Communities - understand the 'nation-ness' as a cultural artefact. This immediately brings in a logic of contingency, as Wodak et al. (2009: 186-187) write in The Discursive Construction of National Identity. They argue that there is not one national identity, but that the signifier of the nation is articulated in a variety of ways, and integrated into a variety of discourses, that all struggle over the nation's meaning. Moreover, there are also a variety of identifications with the signifier of national identity possible. In other words, national identity is not a static concept, but always open to contestation, re-articulation and struggle. The nation does have a spatial component, as, for instance, the notion of the homeland indicates, but when the signifier of the nation becomes articulated with the state, we enter the realm of nationalism, which combines the nation-as-people and the nation-(as-)state, as Billig (1995: 24) argues. Nationalism still has the nation as a nodal point but it adds a second nodal point, namely sovereignty, which implies that nations have political authority which is translated into their entitlement to establish a state for themselves.

Place-based identities are not restricted to the level of the state, though. One example is the notion of urban identity, which refers to 'the collective identity of inhabitants of a city, including shared ideas of belonging, attachment, affiliation, and community’ (Mah 2014: 7). As also rural, regional and subnational identities exist, there are several other concepts that have been developed to refer to these types of identifications, as, for instance, localism and regionalism. And there are supranational or (pan-)continental identities, of which the European identity is one example. Again, we find here a sense of belonging (to a community) and sharing - of (a) similar space(s), history/ies, culture(s), religion(s), language(s) or other elements - but this time in relationship to an entire continent, with all the diversity that this entails. Still, as Delanty and Rumford (2005: 50) write: 'European identity is a question of collective identity and as such, theoretically, is no different from the question of national identity. Even though some authors argue that a European identity does not exist (see Paasi 2001; Pinterič 2005), it is arguably - similar to other place-based identifications - an object of discursive struggle (Aydın-Düzgit 2012: 8), further complicated by the existence (and active identity-building interventions) of the European Union.

As Galpin (2017: 22) writes, these place-based identities are not mutually exclusive. They can coexist, in hierarchical or non-hierarchical ways. This so-called 'marble cake' identity model (Risse 2010: 25) does not always apply to all place-based identities, because - as, for instance, Hooghe and Marks (2009) have argued - these identities are sometimes articulated in mutually exclusive fashions. Still, this is part of a broader discussion on the overdetermined nature of identities (Laclau 1996: 103), as human subjectivity exists through the contingent intersection of a wide variety of identities - including place-based, gender, family, sexual, ethnic, professional and other identities. Not only are these different identities object of discursive struggles, 
resulting in particular hegemonic articulations, within different (political) communities, but individuals will also identify in always unique ways with these intersecting identities, only adding to the specificity and contingency of their articulations. This contingency also implies that the balance (and hierarchy) between these different identity components may shift over time. For instance, Habermas's (2001) analysis of what he calls the 'postnational constellation' combines the idea that the role of the nation-state as object of identification has decreased, with a search to establish new grounds to protect the democratic nature of new constellations.

\section{DISCOURSES ON EUROPEANITY}

The identifications with a European identity can be further unpacked, as the signifier Europe is articulated in a variety of ways. In other words, subjects can identify as European, but being European can have different meanings. Different concepts have been used to capture this being European: Europeanity, Europeanness and Europeanism, but they all assume that Europe can be constructed as distinct, also bringing in different constitutive outsides that support this European particularity. For instance, Smith (1991: 174) mentions 'the heritage of Roman law, Judeo-Christian ethics, Renaissance humanism and individualism, Enlightenment rationalism and science, artistic classicism and romanticism, and above all, traditions of civil rights and democracy'.

An older example is Jaspers' (1947) discussion of the 'European spirit', where he starts by saying that Europe is 'the bible and antiquity', then lists an impressive number of authors and places, only to add that it concerns 'an immeasurable wealth of spirit, morality, faith' (Jaspers 1947: 9). But Jaspers also offers a second route to know Europe, which is for him captured through three keywords: freedom, history and science. Not unlike Jaspers, a considerable number of the discourses that articulate 'being European' are deeply essentialist, fixating Europe as 'a paragon of international virtues: a community of values held up by Europeans and non-Europeans alike as an exemplar for all to emulate' (Judt 2005: 798), slowly forgetting the lessons of the Second World War that were still deeply engrained in Jaspers' writings.

These essentialist discursive configurations are not restricted to more philosophical writings, but, as Stavrakakis (2005: 82) remarks, European identity, and being European, also features prominently in a series of (pre-)European Union policy documents, including the Solemn Declaration of the European Union (1983) and the Single European Act (1987). Another example is the Treaty of Lisbon (2007), which - at its very start (namely in Article 2) - lists a series of values that are claimed to constitute the European Union, including gender equality, non-discrimination and justice.

More relationist approaches (e.g. Delanty 1995) argue that Europeanity is (and has been) constructed in antagonistic relationships with constitutive outsides. Interestingly, also Jaspers (1947: 7) mentions several of these constitutive outsides when he refers to the European colonisation of the globe, 'when the white man asserted his privilege', but also when he points out that 'Europe was never alone', as it was threatened by 'the Persian, Islam, the Mongols, the Normans, the Hungarians, the Turks'. Delanty (1995: 2) concurs with the existence of this particular discursive construction of Europe, but combines it with the need for critique: 'there appears to be widespread consensus today that the cultural foundation of Europe is deeply rooted in Latin Christendom, humanist values and liberal democracy (Kundera, 1984). I hope to be able to show that these beliefs are ungrounded, or at best mystifying $<\ldots>$ '. 
Non-essentialist approaches point to the diversity of the constitutive outsides that have played a role in the history of the discursive construction of Europe, and I want to very briefly touch upon three important ones. Colonialism is one key component of, and stage in, the construction of Europeanity. Colonialism was (and is), as Said (1995) argued, structured through a set of binary oppositions - savage/civil, primitive/modern, close to nature/ technologically developed, etc. - that constructed Europe as superior. To use Said's (1995: 7) words: 'it can be argued that the major component in European culture is precisely what made that culture hegemonic both in and outside Europe: the idea of European identity as a superior one in comparison with all the non-European peoples and cultures.' A second, even older constitutive outside of Europeanity is Islam. The long-term treat of the conquest of Europe, by Muslims, consolidated Christianity as a 'powerful myth of legitimation' (Delanty 1995: 26), which removed much of the internal diversity from sight. It resonates until today, where in later constructions, also in relation to Turkey, Europe is articulated as 'greater than and has surpassed the stage of Christianity, [while] the world of Islam is still mired in religion and primitivity' (Aydın-Düzgit 2012: 34). Finally, a third constitutive outside that was particularly important during the 20th century, was the undemocratic other, partially internal and partially external to Europe. What Delanty (1995: 111) called the 'fascist myth of Europe' became seen, after the Second World War, as non-European, thus constructing another Europeanity. Similarly, the Cold War pitched the undemocratic Soviet Union other against Europe, again rearranging the geographical map of Europe - excluding, for instance, key cities of Mitteleuropa, Prague and Budapest - and aligning Europe with the USA across the Atlantic. This latter construction of Europe led to the symbolic removal of the Soviet Union from Europe altogether (Paasi 2001: 12) and supported a call for the Central-Eastern European countries to 'Return to Europe' (Risse 2000: 14), together with concerns about the americanisation of Europe. With the collapse of the Soviet empire (but also of communist Yugoslavia and Albania), this constitutive outside lost much of its strength, and as Schlesinger (1992: 20) commented - with some visionary talent - already in the early 1990s, 'Islam has in some respects begun to fill the void brought about by the Soviet empire's collapse.'

\section{DISCOURSES ON EUROPEANISATION}

Europeanisation is a related discourse that articulates European identity and Europeanity with a temporal dimension and a process of intensification. It is, in other words, a discourse of becoming, which authors such as Risse (2010: 10) label as the 'Europeanization of national identities. This change process varies, though, as in more minimal versions, it captures the creation or establishment of a European identity and the discourse of Europeanity, making it available for identification and providing meaning to Europe as a cultural space. But Europeanisation also captures, in more maximalist versions, the hegemonisation of a European identity and Europeanity, victoriously concluding the discursive struggle with other - competing - place-based identities (Delanty, Rumford 2005: 20; Sassatelli 2009: 1).

As European identity and the Europeanity discourse can have many different - often competing - articulations, also the question what it is that needs to be intensified becomes open to articulation. This brings Delanty and Rumford (2005: 19) to write that 'the discursive logic of Europeanization is highly contingent. There are no authoritative definitions of what constitutes the "we", the "other", "inside" or "outside". When the focus is on European versus national identity, then Europeanisation can imply the (fear for the) destruction or erasure of 
national identity (Edensor 2002: 111), or the co-existence of European identities with other identities (Motschenbacher 2016: 134), where in the latter case an intersectional approach to Europeanisation is used (Risse 2010: 25). In the case of the Europeanity discourse, Europeanisation can, for instance, imply the glorification of European culture as was witnessed during the periods of intense colonialism, the erasure of religious diversity through the hegemonisation of Christianity (combined with an anti-Islam rhetoric), or what Delanty (1995: 11) calls a 'Eurocentric ethno-cultural project'. Alternatively, Europeanisation can also be grounded in a recognition of a multipolar world, where the experiments of democracy, participation, pluralism and agonism become intensified. To use Laclau's (1996: 57) dynamics of the particular and universal, Europeanisation is not a given and universal concept, it is a particular discourse that is engaged in a struggle for hegemony, in order for its desirability to become universal (at least in Europe). Simultaneously, there are many particular elements that struggle over the meaning of the discourse of Europeanisation itself, trying to hegemonise (or universalise) this discourse.

Finally, analyses of the Europeanisation process are also connected to different locations and actors. First, discourses are dependent on communication platforms to circulate and offer themselves for identification, but these platforms have their specificities, that can allow and disallow for discourses to reach particular groups. These barriers are not always unsurmountable, as translations, (cross-)referencing and content exchanges remain possible. The theoretical concept that has often been used here is the notion of the European public sphere, which refers to both the circulation of European identity and Europeanity discourses ('being European') and to the process of Europeanisation ('becoming European'). It is important here to recall Habermas's (1974: 49) seminal definition of the public sphere when he wrote that 'A portion of the public sphere comes into being in every conversation in which private individuals assemble to form a public body. This serves as an immediate reminder that not only media organisations form (part of) the public sphere (Koopmans, Statham 2010; Pérez 2013), but that also, for instance, the educational field plays a significant role (Soysal 2002).

Together, these (different parts of the) public spheres (or public spaces) allow for the circulation of the diversity of (competing) discursive components that make up European identity and Europeanity, which also includes - but is not restricted to - addressing Europe (and the European Union as political entity) explicitly. For instance, Statham (2010: 5) argues that these public spheres increase the European Union's visibility, which in turn provides an opportunity for citizens to become politically engaged, which also includes their ability to contest the European Union's policies. Europeanisation also implies what Statham (2010: 5) calls 'the transformation of national public spheres', where content (and the discourses embedded within it) transcends national boundaries. It is what Habermas (2006: 102) describes as the process where 'the circuits of communication within the national arenas open themselves up to one another while themselves remaining intact'. Moreover, a diversity of actors enters these public spheres (or spaces) (Sassatelli 2009: 42). Obviously, these include 'Eurocentric institutions, most notably the European Union itself' who are 'encouraging or, depending upon one's point of view, imposing Europeanisation upon reluctant populations' (Miller et al. 2012: 1). But this also includes, for instance, social movements, a process that authors such as della Porta (2020, see also della Porta, Caiani 2009) have labelled 'Europeanisation from below'. 


\section{EUROPEAN MATERIAL PRACTICES}

My emphasis on the discursive interpretations of European identity, Europeanity and Europeanisation hides the dominance of the more materialist approaches in many fields of study. If we focus on Europeanisation ${ }^{*}$ and take Olsen's (2002: 923-924) overview as illustration, we can find what he terms 'five possible uses' of the Europeanisation concept: 'changes in external boundaries', 'developing institutions at the European level', 'central penetration of national systems of governance', 'exporting forms of political organization', and 'a political unification project'. Similarly, Harmsen and Wilson (2000: 13) refer to 'eight usages of the term Europeanization', where only one component (namely, the 'reconstruction of identities') refers to the discursive.

These rich and valuable analyses of the materiality of Europeanisation focus - first of all - on structural and institutional changes, whether this refers to legal, political or economic changes. Delanty (1995: 9) points to the state, economy, culture and society, adding that 'When we survey the history of the European idea it can be seen how it was always articulated in terms of the first three.' Delanty (1995: 9) discusses here the creation of political unity (ranging from 'Holy leagues and alliances of Christendom' to the European Union), in close connection with the creation of a capitalist order - a vital component that is often neglected. These transformations are also connected to, and supported by, legal transformations, including the creation of European law, the convergence of national legal systems, and what Snyder (2000: 4) calls the 'juridification of politics', for instance, through the creation of the European Court of Justice.

Delanty's (1995: 9) critique on the absence of society-focussed approaches, with which he referred to the absence of discussions on civil society and public sphere, have - in the meanwhile - largely been remedied. For instance, a decade later, Delanty and Rumford (2005: 7) themselves published Rethinking Europe, which had the explicit ambition 'to go beyond institutional frameworks to examine the dynamics of society'. For instance, discussions about the Europeanisation from below deal with the material 'transformation of national NGO sectors' (Gray, Statham 2005: 879), and the creation of supra- and transnational NGOs. Also the discussions on the European public sphere(s) are deeply material, as these are concerned with the creation of material structures that allow publics to engage in political conversation (overcoming material borders), but also with the audiences' practices of non-interactive simultaneity (watching screens at the same time) and material interaction. Relatedly, discussions on European film (studies) not only warn that 'research into European cinema still equals research into discrete national cinemas' (Bergfelder 2015: 315), but also point to transnational co-productions, distribution and strategies of accessibility (e.g. dubbing and subtitling).

As Borneman and Fowler's (1997: 497) focus on the situations 'where peoples of Europe engage in face-to-face encounters with each other', it illustrates that Europeanisation can also be located at the very micro-level of embodied practices. European (nation-)states, with their territories, tend to privilege and facilitate intra-border movements, creating material concentrations of the bodies of their citizens. Europeanisation here implies increased material trans-border mobility, generating contact zones, or 'social spaces where cultures meet, clash, and grapple with each other, often in contexts of highly asymmetrical relations of power' (Pratt 1991: 34). Here, as Keinz and Lewicki (2019) argue, also the materiality of the body itself matters, to be inscribed with racialised, gendered, classed discourses of (non-)Europeanity.

A similar type of argument can be made for the materiality of European identity and Europeanity, but has been left out for reasons of space. 


\section{CONCLUSION: TOWARDS THE EUROPEAN DISCURSIVE-MATERIAL ASSEMBLAGE}

These discourses and materialities of European identity, Europeanity and Europeanisation are deeply entangled, with permanent and intense interactions between these two components of social reality. At the same time, the discursive-material approach that was used in this article also allows emphasising the importance of both components and their entanglement, while in different academic fields, they are exposed to different levels of attention, with the discursive still remaining often under-represented. Arguably, instead of analytically privileging one of the two components, it might be more fruitful to focus on European assemblages, that - in always unique ways - combine discourses, signifying practices and many different materials. For instance, public spheres are very much locations where Europeanity is discursively and materially performed, in a variety of ways, sometimes implicitly, and sometimes with explicit reference to Europe, sometimes focussing on European (and in particular European Union) governance structures, and sometimes on everyday practices.

This necessary articulation of the discursive and material matters allows emphasising that Europeanity and Europeanisation are more than the mere aggregation of governance structures, industries and bodies. Without the - explicit or implicit - presence of the signifier Europe in this assemblage, with some degree of identification (and the affects that this brings about), these aggregations are built on an imaginary transcendence of the European (nation-)states and their national identities. In other words, if citizens on interconnected public spheres define their interlocutors as others, and not part of the European self, then there is little reason to refer to European identity, Europeanity and Europeanisation.

This discursive-material approach also foregrounds the contingency of these constructions. European identity, and the discourses of Europeanity and Europeanisation are not given and essentially fixed. They are deeply contested, and sometimes in their entirety rejected. But when their right of (discursive) existence is accepted, we are still dealing with intense discursive struggles over their exact articulations. This is where the discourses of Europeanity and Europeanisation also touch each other, because being European is also always becoming European, and becoming European has many different directions. And this is where the ethical comes in, as - when confronted with this multitude of possible constructions of European identity, Europeanity and Europeanisation, and the dangers of European antagonistic nationalism - we also need to ask the question what it means to become better Europeans.

\section{ACKNOWLEDGEMENTS}

This publication is part of a project that has received funding from the European Union's Horizon 2020 Research and Innovation Programme under Grant Agreement No. 101004488.

\section{References}

1. Anderson, B. 1996. Imagined Communities: Reflections on the Origins and Spread of Nationalism. London: Verso.

2. Aydın-Düzgit, S. 2012. Constructions of European Identity: Debates and Discourses on Turkey and the EU. Basingstoke: Palgrave Macmillan.

3. Bergfelder, T. 2005. 'National, Transnational or Supranational Cinema? Rethinking European Film Studies', Media, Culture \& Society 27(3): 315-331.

4. Billig, M. 1995. Banal Nationalism. London: Sage.

5. Borneman, J.; Fowler, N. 1997. 'Europeanization', Annual Review of Anthropology 26: 487-515. 
6. Carpentier, N. 2017. The Discursive-Material Knot: Cyprus in Conflict and Community Media Participation. New York: Peter Lang.

7. Delanty, G. 1995. Inventing Europe: Idea, Identity, Reality. London: Macmillan.

8. Delanty, G.; Rumford, C. 2005. Rethinking Europe: Social Theory and the Implications of Europeanization. London and New York: Routledge.

9. Edensor, T. 2002. National Identity, Popular Culture and Everyday Life. Oxford and New York: Berg.

10. Galpin, C. 2017. The Euro Crisis and European Identities Political and Media Discourse in Germany, Ireland and Poland. Basingstoke: Palgrave Macmillan.

11. Gray, E.; Statham, P. 2005. 'Becoming European? The Transformation of the British Pro-migrant NGO Sector in Response to Europeanization', Journal of Common Market Studies 43(4): 877-898.

12. Habermas, J. 1974. 'The Public Sphere: An Encyclopedia Article (1964)', New German Critique 3(autumn): $49-55$.

13. Habermas, J. 2001. The Postnational Constellation: Political Essays. Cambridge: Polity Press.

14. Habermas, J. 2006. Time of Transitions. Cambridge: Polity Press.

15. Harmsen, R.; Wilson, T. M. 2000. 'Introduction: Approaches to Europeanization', Yearbook of European Studies 14: 13-26.

16. Hooghe, L.; Marks, G. 2009. 'A Postfunctionalist Theory of European Integration: From Permissive Consensus to Constraining Dissensus', British Journal of Political Science 39(1): 1-23.

17. Jaspers, K. 1947. Vom europäischen Geist: Vortrag gehalten bei den Rencontres Internationales de Genève. Munich: Piper.

18. Judt, T. 2005. Postwar: A History of Europe since 1945. Portsmouth: Heinemann.

19. Keinz, A.; Lewicki, P. 2019. 'Who Embodies Europe? Explorations into the Construction of European Bodies', Anthropological Journal of European Cultures 28(1): 1-18.

20. Koopmans, R.; Statham, P. (eds.). 2010. The Making of a European Public Sphere: Media Discourse and Political Contention. Cambridge: Cambridge University Press.

21. Laclau, E. 1996. Emancipation(s). London: Verso.

22. Mah, A. 2014. Port Cities and Global Legacies: Urban Identity, Waterfront Work, and Radicalism. Basingstoke: Palgrave Macmillan.

23. Miller, R.; Domecka, M.; Schubotz, D.; Svašek, M. 2012. 'Dimensions for the Expression of European Identity', in The Evolution of European Identities: Biographical Approaches, ed. R. Miller and G. Day. Basingstoke: Palgrave Macmillan, 1-20.

24. Motschenbacher, H. 2016. Language, Normativity and Europeanisation: Discursive Evidence from the Eurovision Song Contest. Basingstoke: Palgrave Macmillan.

25. Olsen, J. P. 2002. 'The Many Faces of Europeanization', Journal of Common Market Studies 40(5): 921-952.

26. Paasi, A. 2001. 'Europe as a Social Process and Discourse: Considerations of Place, Boundaries and Identity', European Urban and Regional Studies 8(1): 7-28.

27. Pérez, F. S. 2013. Political Communication in Europe: The Cultural and Structural Limits of the European Public Sphere. Basingstoke: Palgrave Macmillan.

28. Pinterič, U. 2005. 'National and Supranational Identity in Context of the European Integration and Globalization', Društvenaistraživanja 3(77): 401-420.

29. Porta, D. della. 2020. 'Europeanisation from Below: Still Time for Another Europe?', European Journal of Cultural and Political Sociology 7(3): 225-241.

30. Porta, D. della; Caiani, M. 2009. Social Movements and Europeanization. Oxford: Oxford University Press.

31. Pratt, M. L. 1991. 'Arts of the Contact Zone', Profession 91: 33-40.

32. Rietbergen, P. 2015. Europe: A Cultural History. 3rd edn. London/New York: Routledge.

33. Risse, T. 2010. A Community of Europeans? Transnational Identities and Public Spheres. Ithaca and London: Cornell University Press.

34. Said, E. 1995. Orientalism. Penguin: London.

35. Sassatelli, M. 2009. Becoming Europeans: Cultural Identity and Cultural Policies. Basingstoke: Palgrave Macmillan.

36. Schlesinger, P. 1992. 'Europeanness. A New Cultural Battlefield?', Innovation 5(2): 11-23.

37. Smith, A. D. 1991. National Identity. Harmondsworth: Penguin.

38. Snyder, F. 2000. 'The EUI Law Department and the Europeanisation of Law: An Introduction', in The Europeanisation of Law, ed. F. Snyder. Oxford and Portland: Hart, 1-11. 
39. Soysal, Y. 2002. 'Locating Europe', European Societies 4(3): 265-284.

40. Statham, P. 2010. 'Introduction: Europe's Search for a Public', in The Making of a European Public Sphere: Media Discourse and Political Contention, eds. R. Koopmans and P. Statham. Cambridge: Cambridge University Press, 1-10.

41. Stavrakakis, Y. 2005. 'Passions of Identification', in Discourse Theory in European Politics, eds. D. Howarth and J. Torfing. Basingstoke: Palgrave Macmillan, 68-92.

42. Wodak, R.; de Cillia, R.; Reisigl, M.; Liebhart, K. 2009. The Discursive Construction of National Identity. 2nd edn. Edinburgh: Edinburgh University Press.

NICO CARPENTIER

\title{
Europietiškumas kaip rinkinys: diskursyvioji ir materialioji europinès tapatybès, europietiškumo ir europeizacijos analizè
}

\begin{abstract}
Santrauka
Skirtingos akademinès disciplinos paprastai taiko skirtingas europinès tapatybès, europietiškumo ir europeizacijos tyrimo prieigas, dažniausiai akcentuodamos šių tyrimo objektų materialiuosius ir struktūrinius elementus. Šiame straipsnyje taikoma diskursyvioji-materialioji analizė, kuri pripažịsta materialiųjų elementų svarbą, bet ịtraukia šiuos elementus ne $\mathfrak{i}$ hierarchinị, o $\mathfrak{i}$ horizontalųji santykị su diskursyviaisiais elementais. Remiantis išsamia europinę tapatybę, europietiškumą ir europeizaciją nagrinèjančios mokslinès literatūros apžvalga, pabrèžiama diskursyvioji šių sąvokų prigimtis. Straipsnyje analizuojama, kaip minètos sąvokos įsitraukia ị kovą su kitomis vieta grindžiamomis (place-based) tapatybėmis ir diskursais; akcentuojamas šių sąvokų junginių esminis atsitiktinumas, žvelgiant iš ilgą istorinę patirtị turinčių esencialistinio pobūdžio junginių perspektyvos. Antrojoje straipsnio dalyje analizuojami materialieji minètų sąvokų dèmenys, išskirtinį demesị skiriant europeizacijos sąvokai. Galiausiai ši analizè pateikiama kaip argumentas, kad Europa būtų suprantama kaip junginys, kuriame ji realizuojama per visada unikalius ir atsitiktinius diskursyviųjų ir materialiųjų elementų junginius.
\end{abstract}

Raktažodžiai: europinè tapatybè, europietiškumas, europeizacija, buvimas europiečiais, tapimas europiečiais, diskurso teorija, naujasis materializmas, ịsitraukimas, junginys 